\title{
The impact of visualization tools in distance english language learning: the experience of the russian university teachers
}

\section{O impacto das ferramentas de visualização no aprendizado de inglês à distância: a experiência dos professores universitários russos}

\section{El impacto de las herramientas de visualización en el aprendizaje del inglés a distancia: la experiencia de los profesores universitarios rusos}

\author{
Tatyana llinichna Golubeva ${ }^{1}$ (D) Elena Vladimirovna Skudnyakova ${ }^{2}$ (D), \\ Natalia Nikolaevna Kasatkina ${ }^{3}$ (D) Svetlana Vladimirovna Dandanova ${ }^{3}$ (D),
}

Oxana Innokentyevna Dagbaeva ${ }^{4}$

\footnotetext{
${ }^{1}$ Russian State Social University, Moscow, Russia.

2 K.G. Razumovsky Moscow State University of Technologies and Management (First Cossack University), Moscow, Russia.

${ }^{3}$ Demidov Yaroslavl State University, Yaroslavl, Russia.

${ }^{4}$ Peoples' Friendship University of Russia (RUDN University), Moscow, Russia.
}

Corresponding author:

Tatyana Ilinichna Golubeva

Email: tatyanailinichna.golubeva@mail.ru

How to cite: Golubeva, T. I., Skudnyakova, E. V., Kasatkina, N. N., Dandanova, S. V., \& Dagbaeva, O. I. (2021). The impact of visualization tools in distance english language learning: the experience of the russian university teachers. Revista Tempos e Espaços em Educação, 14(33), e16111. http://dx.doi.org/10.20952/revtee.v14i33.16111

\begin{abstract}
The article is aimed at a detailed examination of the prerequisites for the introduction of visual content into the educational process in the foreign language course during distance learning and at defining a list of prerequisites for its successful processing by students. The article proves that the search for new trends and approaches to education leads to new goals and new types of knowledge. All innovations in higher education contribute to the formation of a new image of future professionals. The relevance of the problems of higher education technologization is associated with the countless number of innovations, among which the authors single out the visualization of educational information in distance learning. The article shows the importance of visualization in distance education. The given technology includes both visual presentations of information and the development of visual thinking during the educational process. Educational material and an effective visual teaching method allow making the educational process interesting and nonstandard and increasing students' motivation to learn English. Thus, the visualization of educational information is a tool for distance learning technology. The article identifies the preferable visualization tools based on the survey of students based on the results of the use of visualization
\end{abstract}


in distance English language learning. According to the summary of the results of distance English language learning, it is proposed to divide the visualization process into several stages.

Keywords: Distance learning. English language. Visualization tools. Visualization forms. Visualization functions.

\section{RESUMO}

O artigo tem como objetivo um exame detalhado dos pré-requisitos para a introdução do conteúdo visual no processo educacional do curso de línguas estrangeiras durante a educação a distância e definir uma lista de pré-requisitos para o seu processamento com sucesso pelos alunos. $O$ artigo comprova que a busca por novas tendências e abordagens da educação leva a novos objetivos e novos tipos de conhecimento. Todas as inovações no ensino superior contribuem para a formação de uma nova imagem dos futuros profissionais. A relevância dos problemas da tecnologização do ensino superior está associada às inúmeras inovações, entre as quais os autores destacam a visualização de informações educacionais em EAD. $O$ artigo mostra a importância da visualização na educação a distância. A tecnologia fornecida inclui apresentações visuais de informações e o desenvolvimento do pensamento visual durante o processo educacional. O material educacional e um método de ensino visual eficaz permitem tornar o processo educacional interessante e fora do padrão e aumentar a motivação dos alunos para aprender inglês. Assim, a visualização de informações educacionais é uma ferramenta para a tecnologia de ensino a distância. $O$ artigo identifica as ferramentas de visualização preferíveis com base na pesquisa de alunos com base nos resultados do uso da visualização no ensino de inglês à distância. De acordo com o resumo dos resultados do ensino de inglês a distância, propõe-se dividir o processo de visualização em várias etapas.

Palavras-chave: Ensino à distância. Língua Inglesa. Ferramentas de visualização. Formulários de visualização. Funções de visualização.

\section{RESUMEN}

El artículo tiene como objetivo un examen detallado de los requisitos previos para la introducción de contenido visual en el proceso educativo en el curso de lengua extranjera durante el aprendizaje a distancia y la definición de una lista de requisitos previos para su procesamiento exitoso por parte de los estudiantes. El artículo demuestra que la búsqueda de nuevas tendencias y enfoques de la educación conduce a nuevas metas y nuevos tipos de conocimiento. Todas las innovaciones en la educación superior contribuyen a la formación de una nueva imagen de los futuros profesionales. La relevancia de los problemas de la tecnificación de la educación superior está asociada a la innumerable cantidad de innovaciones, entre las que los autores destacan la visualización de la información educativa en la educación a distancia. El artículo muestra la importancia de la visualización en la educación a distancia. La tecnología dada incluye tanto presentaciones visuales de información como el desarrollo del pensamiento visual durante el proceso educativo. El material educativo y un método de enseñanza visual eficaz permiten hacer que el proceso educativo sea interesante y no estándar y aumentar la motivación de los estudiantes para aprender inglés. Así, la visualización de información educativa es una herramienta para la tecnología de educación a distancia. El artículo identifica las herramientas de visualización preferibles basadas en la encuesta a los estudiantes basada en los resultados del uso de la visualización en el aprendizaje del idioma inglés a distancia. Según el resumen de los resultados del aprendizaje del idioma inglés a distancia, se propone dividir el proceso de visualización en varias etapas.

Palabras clave: La educación a distancia. Idioma en Inglés. Herramientas de visualización. Formas de visualización. Funciones de visualización. 


\section{INTRODUCTION}

The significant acceleration of the pace of life, the increased amount of information, the rapid development of information and communication technologies, and their distribution in all spheres of life caused the appearance of some new cognitive aspects of students. This includes the intensification of visual teaching aids, which leads to the emergence of a new information society with a visual or computer type of thinking (Dudin et al., 2019; Vinichenko et al., 2018). At the same time, the transition to distance learning caused by the pandemic caused the problem of the choice of the presentation forms for new information. One of the ways to solve this problem is the use of various visualization tools of the information flow since the cognition of a modern person perceives images more efficiently than verbal means. In consequence, the scientific and pedagogical community pays close attention to the technology of visualization (Rabadanova et al., 2020; Bukhteeva et al., 2019; Presnukhina et al., 2020).

Today, the use of visualization tools in the educational process is an important issue, since it presents a large amount of information in an accessible, systematized, and easy-to-understand form, attracts attention, and, therefore, provides a comprehensive and complete formation of any image or concept. Visualization tools can be used not only in teaching but also in presenting complex information (Sharonova \& Avdeeva, 2020).

Visual communication is one of the most interesting, potentially useful, and powerful learning tools. Any image conveys a certain meaning, it contains a story that is more difficult and longer in terms of the words, since the visual form of communication is partially or completely based on visual perception. Visual language can spread knowledge more efficiently than any other means of communication (Carr, 2003).

The term "visualization" was first proposed by the Swiss psychologist Carl Gustav Jung, who defined it as a phenomenon, which is inherent in the human psyche and is based on the ability of a person to think in images. Visualization (lat. "visualis") is understood as a representation of a physical phenomenon or process in a form convenient for visual perception (Azimov \& Shchukin, 2009). It is also understood as an information map and an action as a form of representation and simulation of semantic space. It helps to present any object holistically, provides a deeper understanding of complex information, reveals hidden relationships, and makes possible a multiperspective vision of information (Stupina, 2009).

The scientists distinguish between knowledge visualization and information visualization. Knowledge visualization tools the creation and distribution of knowledge between people with the help of striking and rational expressive means. Visualization also allows communicating experiences, attitudes, values, thoughts, predictions. Thus, it helps interlocutors to correctly reproduce and apply them. Examples of knowledge visualization patterns are heuristic sketches, concept diagrams, visual metaphors, knowledge animations. Knowledge visualization should not be confused with information visualization, which is the improvement of the search and access to information, optimization of the reproduction of big databases (especially within human-computer interaction) (Grebenyukov, 2014).

The human vision conveys about $90 \%$ of the information, thus, it is not surprising that in evolution, a person has developed the ability to think in images that are preserved in the inner part of the personality, in the unconscious part of his psyche (Reavey, 2010). Accordingly, it turned out that during the knowledge assimilation, visuals are practically more significant for the younger generation, because they are informative, they lead to a deeper understanding of new information and its rapid transmission to the long-term memory of students. It is clear that during the educational process the teacher traditionally uses visualization.

However, visibility and visualization are not the same, despite the psychological connection between them. To study the functional features and to form a list of visualization tools, it is important to differentiate between "visible" and "visual" means, which should not be confused in 
pedagogical techniques. Considering the essence of the compared concepts, it is possible to conclude that a visible means is an object (or an image), while a visual means is an indivisible result, a product of a person's mental activity. Therefore, the visualization should be studied as the transformation of mental content into a visible image. Visibility results in visualization, it is a way of perceiving an object, which leads to the creation of visual images, and visualization is the result of this perception. The purpose of visualization is to adapt new information, which makes it easy to assimilate and to create a worldview.

\section{LITERATURE REVIEW}

Visualization as a teaching principle has been used for a long time in methodology and pedagogy (Ya.A. Komenskii, I. Pestalozzi, K.D. Ushinskii, and others).

There are various approaches to the concept of visualization in the scientific literature (Table 1).

Table 1. The concept of visualization.

\begin{tabular}{ll}
\hline Source & Concept \\
\hline Rose, 2007 & $\begin{array}{l}\text { a systematic, rule-based, external, permanent, and graphic representation that displays information } \\
\text { in a form that is convenient for comprehension and that develops a perfect understanding or } \\
\text { experience of communication } \\
\text { an information block created with the help of an image and typographic elements, which } \\
\text { accompanies or replaces text information and makes it possible to understand or to facilitate the } \\
\text { understanding of events, actions, or any important aspects } \\
\text { Lavrentev et } 2005 \\
\begin{array}{l}\text { al., 2012 } \\
\text { Sidelnikova, } \\
\text { 2016 }\end{array}\end{array} \begin{array}{l}\text { a pedagogical method based on the principle of visibility, within which a symbolic presentation of the } \\
\text { content, functions, structure, and stages of a process or phenomenon is carried out through } \\
\text { schematization and associative-illustrative series }\end{array}$ \\
\hline
\end{tabular}

A.A. Zakharova and A.V. Shklyar (2013) note that the main task of visualization should be considered to be the creation of an additional, sometimes a single opportunity for the accelerated understanding of a certain amount of information. K.V. Kiuru and E.E. Popova (2018) examine the use of digital visual content in the educational process of a higher education institution and note that visualization is a response to the challenges of modern social reality which makes it possible to individualize the educational space. According to Z.N. Kodzova (2017), structuring, schematization, and, most importantly, compression of educational material (the volume of which increases constantly) are implemented only because of the use of a large number of visual means in the educational process.

Visualization is effective, first of all, when it is used as a means of communication. It helps to facilitate the perception and understanding of information, which is confirmed by modern research in the field of visual communication (Ahn \& Brusilovsky, 2009).

D. Lunsford singles out three main characteristics that ensure the effectiveness of any methods of visual communication:

- attracting attention: communication should attract the audience;

- understanding: communication should effectively transfer knowledge and encourage a clear understanding of information. This means that the reader should be able to easily understand the presented information;

- assimilating: communication should provide knowledge that is easy to remember. This means that the user should easily remember the visualized information (Lunsford, 2009).

A.P. Malkina (2008) considers the visualization of the studied material to be one of the metacognitive skills, according to which the teaching of a foreign language functions. If a student can create mental images of what they read or listen to, then it proves that the material is 
understood. These images should be created in pre-text exercises, in the process of reading, and post-text work. This deepens understanding since visualization links together the background knowledge and new information. The main goal of knowledge visualization is to stimulate cognitive processes in the transfer of knowledge.

The textbooks, in which visualization tools are applied, activate the process of perception and understanding of information, ideas, and concepts, increase the ability to think critically, develop an organized idea and improve the assimilation of information (Card et al., 1999). Considering the above-mentioned, visualization tools have a high potential, which can be used as a useful means of improving the quality of education. The main advantage of visualization tools is to provide information density and clarity of educational materials and to appeal to the existing knowledge and experience of the user. Visualization becomes a facilitator in the process of choosing the type of information perception.

K.W. Hall and R. Obregon (2002) highlight the fact that when perceiving educational material using visualization, a person can cover simultaneously all the components, trace possible connections between them and categorize them according to the degree of significance and similarity. All this, according to the researchers, is the basis for a deeper understanding of the new information. It facilitates the establishment of the new connections between students' personal experience and the content of abstract knowledge that is far from it and serves as a means of their concretization.

According to V.L. Averbukh (2013), the creation of multimedia models of knowledge representation should make it possible to make images of models as objects for logical thinking, as well as images of multimedia pictures that are used by figurative thinking.

The researchers who study educational methods have proved that in three days after the lecture, students can remember only $10 \%$ of what they heard, $35 \%$ of what they saw. Yet, $65 \%$ of them can reproduce the content of the lecture if it was presented in oral form with the use of visual aids (Xu et al., 2014).

According to the researchers, the skillful use of visualization tools can also ensure the formation of the subject and general competencies (the required volume and level of knowledge and experience in a specific type of activity) and influence the acquisition of professional competencies formed based on knowledge, skills, and abilities of a specialist to perform types of professional tasks defined by the standard (Klement, 2017).

Thus, the use of visualization technologies helps to solve one of the main problems of modern education. To be more precise, it helps to stimulate interest in learning and to develop cognitive interest.

One of the most detailed classifications of visualization tools belongs to R. Lengler and M.J. Eppler (2007). It is presented in the form of a periodic system and includes 6 main groups, classified according to the object of presentation (Table 2).

Table 2. The classification of visualization tools according to the object of presentation.

\begin{tabular}{lll}
\hline No. & Object of visualization Characteristics \\
\hline 1 & $\begin{array}{l}\text { data visualization } \\
\text { information } \\
\text { visualization } \\
\text { strategy visualization }\end{array}$ & $\begin{array}{l}\text { visual representations of quantitative data in schematic form } \\
\text { interactive visual representations of data to amplify cognition }\end{array}$ \\
4 & $\begin{array}{l}\text { concept visualization } \\
\text { metaphor } \\
\text { visualization } \\
\text { compound } \\
\text { visualization }\end{array}$ & $\begin{array}{l}\text { visual tool for detailed planning and management of projects, ideas } \\
\text { simple tool for ensuring the assimilation of complex content }\end{array}$ \\
6 & consists of several of the aforementioned formats \\
\hline
\end{tabular}


Modern global information sources contain many video and animation materials that can be effectively used in the classroom by a foreign language teacher. The preparation of a lesson using ICT tools for visualization of educational material includes a selection of visualization tools; preparation of an explanatory text if the tool does not have audio material; development of the exercises to perform before, during, and after viewing; preparation of situations for the speaking activities. The materials selected by a teacher for visualization should correspond to the topic and content of the lesson (for example only one fragment of the material may be used).

The researchers focus on the use of typical visualization tools in English language learning (Table 3) (Izotova \& Buglaeva, 2015; Syrina, 2016).

Table 3. Typical visualization tools in English language learning.

\begin{tabular}{|c|c|c|}
\hline No. & Visualization tool & Characteristics \\
\hline 1 & photo & $\begin{array}{l}\text { are most often used in textbooks of leading foreign publishing houses and aimed at } \\
\text { presenting the authors/main characters of a text and the scene of action (typical } \\
\text { characters in typical conditions of a different cultural environment) }\end{array}$ \\
\hline 2 & drawing & $\begin{array}{l}\text { a typical tool used to convey as expressively as possible the situational behavior of } \\
\text { the characters of dialogues or polylogues highlighting their emotional state and } \\
\text { reaction to an event }\end{array}$ \\
\hline 3 & map & $\begin{array}{l}\text { the most effective tool for the assimilation and distribution of topographic } \\
\text { information }\end{array}$ \\
\hline 4 & scheme & $\begin{array}{l}\text { a simplified picture that shows the relationship between elements; it is especially } \\
\text { useful for defining the main idea and verbalizing the process of its formation }\end{array}$ \\
\hline 5 & $\begin{array}{l}\text { organigram (or } \\
\text { structure) }\end{array}$ & $\begin{array}{l}\text { Is usually used in an incomplete form to train the independent establishment of } \\
\text { semantic links within a certain category }\end{array}$ \\
\hline 6 & table & standard multidimensional data compression tool \\
\hline 7 & chart & $\begin{array}{l}\text { like a table, it serves to simplify and speed up the analysis and assimilation of static } \\
\text { information }\end{array}$ \\
\hline 8 & graph & visual tool for analyzing and comparing dynamic data \\
\hline 9 & infographics & $\begin{array}{l}\text { a visual tool with the broadest possibilities for the data demonstration with the help } \\
\text { of various creative techniques, the advantages of which are the demonstration of } \\
\text { certain patterns and trends, the correlation between facts and phenomena both in } \\
\text { space and in time }\end{array}$ \\
\hline
\end{tabular}

The article is aimed at defining the prerequisites for the introduction of visual content into the educational process in the foreign language course during distance learning and at defining a list of prerequisites for its successful processing by students.

Research Hypothesis: the use of visualization tools for distance English language learning involves a gradual implementation of the visualization of educational information using special visualization technologies.

Research objectives:

- to define the possibilities of using visualization technologies in distance English language learning;

- to identify the preferable visualization tools based on the survey of students based on the results of the use of visualization in distance English language learning;

- to determine the steps of the visualization process based on the expert survey of teachers.

The article consists of the introduction, the literature review, the descriptions of research methods, the results of the research and their discussion, and the conclusion.

\section{METHODS}

The aims and objectives of using visualization technologies in distance English language learning were based on the creation of conditions for the formation of students' lexical and 
communicative competencies related to knowledge of the theoretical practice-oriented foundations of English.

To achieve the aims set in the work, the following methods were used:

- theoretical analysis, comparison, generalization, and systematization were used to identify the current state of the research problem in the field of pedagogical theory and practice; to determine the content of such concepts as "visualization" and "visualization means". This made it possible to identify the possibilities of using visualization in distance English language learning;

- a survey was used, firstly, to determine the types of visualization tools that simplify distance learning, and which, on the contrary, are perceived as difficult to understand. Secondly, it was used to determine the steps of the visualization process and to give examples of the use of visualization of the educational material in the course of English.

The survey involved university students of the first, second, third, and fourth years, who studied remotely during the pandemic, and experts (English teachers from non-linguistic departments) who used various visualization tools in teaching English.

\section{RESULTS}

To develop techniques to increase the efficiency of using visualization tools and the motivation for learning a foreign language, we surveyed university students of the first, second, third, and fourth years. The respondents had to determine the types of visualization tools that simplify distance learning, and which, on the contrary, are perceived as difficult to understand. The results of the survey on the preferable visualization tools are presented in Table 4.

Table 4. The results of the survey among university students of the first, second, third, and fourth years.

\begin{tabular}{|c|c|c|}
\hline Question & Answer options & Result, \% \\
\hline \multicolumn{2}{|c|}{ What visualization tools do you consider to be effective and photo } & 11 \\
\hline \multirow[t]{7}{*}{ helpful? } & drawing & 9 \\
\hline & map & 13 \\
\hline & table & 19 \\
\hline & chart & 16 \\
\hline & graph & 9 \\
\hline & scheme & 7 \\
\hline & infographics & 16 \\
\hline \multirow[t]{5}{*}{ What are the functions of the visualization tools? } & informational & 41 \\
\hline & aesthetic & 9 \\
\hline & highlighting & 4 \\
\hline & practical & 36 \\
\hline & controlling & 10 \\
\hline \multicolumn{2}{|c|}{ What visualization tools do you prefer from an aesthetic point of photo } & 20 \\
\hline \multirow[t]{7}{*}{ view? } & drawing & 17 \\
\hline & map & 3 \\
\hline & table & 7 \\
\hline & chart & 14 \\
\hline & graph & 10 \\
\hline & scheme & 4 \\
\hline & infographics & 25 \\
\hline \multicolumn{2}{|c|}{ What visualization tools do you prefer when working on a new photo } & 5 \\
\hline \multirow[t]{6}{*}{ complex topic? } & drawing & 2 \\
\hline & map & 4 \\
\hline & table & 24 \\
\hline & chart & 22 \\
\hline & graph & 16 \\
\hline & scheme & 12 \\
\hline
\end{tabular}


According to the results, students are aware of the purpose of using certain visualization tools in various types of educational activities in distance learning, such as: informing, analyzing information, initiating emotional feedback, monitoring. Thus, although in general students prefer photos and drawings from an aesthetic point of view, they prefer the more informative tables and charts when working on a new complex topic.

The importance of infographics for educational activities is worth emphasizing. This visualization tool is the most popular one in terms of demand, information content, and aesthetics, which is not surprising, since the integrated approach and simplification, on which the creation of any product of this category is based, make it popular among Internet users. Thus, in choosing the most effective means of increasing students' motivation to develop concise information, it is advisable to pay attention to the presentation of statistical data, trends, and models in the form of contrasting infographics.

\section{DISCUSSION}

Today, to develop communicative and informational competencies of a highly qualified specialist, it is necessary to form, deepen and intensify within the distance educational process the development of such knowledge, skills, and abilities while working with visualized content, necessary for the ability to take part in professional communication (including in foreign language):

the ability to precisely represent orally or in writing the data from a graph, scheme, map, etc.;

the ability to choose and use an effective lexical and grammatical linguistic means to describe the visualized data;

the ability to create and use speech patterns and cliches for quick participation in the competition of visualized information in written form;

the ability to select vocabulary and appropriate grammatical forms for creating a diagram legend, headlines, inscriptions, footnotes (elliptical constructions, substantiation, abbreviations);

knowledge of the norms and characteristics of the styles of both oral and written professional-oriented and business communication;

the skills to independently search for additional information and analyze it;

the ability to objectively convey factual information without personal evaluation of either the content or the form of visualization.

The summarized results of distance learning fully reflect the complexity of the educational process. Therefore, based on the results of the expert survey of teachers, we propose to divide the complex process of using visualization in distance English language learning into several stages.

Firstly, it is important to identify the goal of a graph, chart, or diagram and to associate it with the benefits of students acquiring visualized data skills. Motivation is a powerful factor in the success of teacher-student collaboration.

Secondly, one should carefully select educational materials according to the preparation level of the audience: authentic materials may be too difficult to understand. The selection of visualization tools for distance English language learning should be based on the following criteria: relevance);

- relevance (correspondence to the interests of the audience or unconditional topic

- up-to-dateness (all information should be new or it should be used for the comparison with updated data for further analysis);

- unambiguousness (students should not be distracted by debates with each other or with the teacher about the content or the interpretation of the material); 
- readability (refers to the format, print quality, font, color scheme. All data should be easy to read or to define according to the presented visual method; it should be borne in mind that certain types of data require a certain visualization method, for example, the chronology of the events is easier to perceive in the form of the timeline). It is advisable to draw students' attention to the simplicity of design as an advantage of content over form and invite them to independently think over alternative visualization possibilities for already existing graphs or schemes;

- one of the modern requirements of the leading publishers for educational materials containing visualization tools (especially authentic ones, such as photographs), is the so-called "real world content". The picture should encourage thinking and emotional response by involving students in a real situation. In the context of teaching a foreign language, photos or infographics with the additional linguistic and cultural aspects are the most effective (they should be significantly different from the socio-cultural realities familiar to the audience);

- aesthetics is an optional requirement because the good quality is subconsciously associated with correctness, therefore, it will increase the motivation of students to process the material.

Thirdly, it is necessary to plan out an optimal number of educational activities for the processing of visualized information, considering the obligatory change of the pace and types of work.

Fourthly, it is necessary to memorize vocabulary and speech cliches in advance both for a general presentation of the content ("The table/graph/diagram... a) provides information about/on...; b) gives information about/on...; c) compares/shows/illustrates...") and for its detailed analysis. However, memorized ready-made phrases do not always correlate with the content of complex professional tables or graphs that are not adapted for educational purposes. In their future professional activity, modern students should be able to independently carry out oral or written analysis of authentic materials containing concise information. Taking this into account, we also advise updating the following knowledge and skills within the work with speech cliches:

1. students' knowledge in the field of word formation and their ability to establish connections between derivatives;

2. students should be focused on the differences in spelling and syntactic structures of titles and captions (especially dealing with the photos):

- the use of articles and adjectives: for example, the phrase "The pandemic deaths of the years 2020 vs 2019" is transformed into "Pandemic deaths of 2020 vs 2019";

- absence of auxiliary verbs even in passive constructions;

- date format and abbreviations;

- differences in translation of, for example, "-ing" forms into Russian: "acquiring" and "mapping" will transform into nouns.

3. it is necessary to clarify the grammatical category of tense, as students may decide that Continuous tense should be used to describe the content of all visualization tools (since it deals with the events or actions). It is necessary to emphasize the need to distinguish between the captions under the photos ("...is laughing/...is wearing") and, for example, under the graphs, for the analysis of which are used:

- Present Simple (facts and the current state of affairs): "GDP tends to increase". Special attention should be paid to the captions under the photos, written in Active or Passive Voice to demonstrate the immediacy;

- Past Simple (completed process or action): "In 2020 GDP dropped to 4\%";

- Present Perfect (recent event or results): "GDP has dropped from 6\% to 4\% currently";

- Future Simple (forecasting): "In 2020 will drop to 8\%". The construction "to be going to" can also be used, especially after the verbs "predict" or "estimate" (including Passive Voice). 
4. students should be familiar with modern recommendations for the presentation of visualization tools: it is better to use Active Voice than Passive Voice, verbal constructions than nominal ones.

The experts note that the actualization and practice of all the above-mentioned linguistic aspects are possible only if the duration of the foreign language course is at least three semesters with at least four academic hours a week. This is due to the need to present or update (in groups with a level of foreign language proficiency not lower than B1) the above-mentioned aspects of semantics, grammar, and syntax. The work with summarized or visualized information, although it is an integral component of studying the main topics of the curriculum, turns out to be the background due to lack of time. However, the comparison of the pace of processing by students of English-language information in the form of text and the form of a table showed that the latter takes $30 \%$ less time (Volzhenina \& Fomenko, 2013).

The implementation of the teacher's creative ideas in achieving a more complete comprehension of the educational materials is facilitated by the expansion of the range of technologies for visualizing educational information. Among the methods of presenting educational material, apart from visual aids, experts also distinguish sketchnoting, pitching, and scribing.

Sketchnoting is a way of structuring information perceived by ear, or fixing one's thoughts. The essence of this phenomenon in visualization technology is putting down important ideas on paper in the form of handwritten texts, diagrams, and other visual elements (Paepcke-Hjeltness et al., 2017).

Pitching is a system of open short presentations, which are used, for example, as a presentation of open lessons during teaching practice, or the presentation of the graduates' projects (El Habbal Jadayel \& Medlej, 2018).

Today, scribing has become a new trend in the education system. It is one of the active teaching methods, which includes the visualization of information using graphic symbols. Over time, American lecturers-designers have begun to turn this unique style of data visualization (hand-drawn diagrams and illustrations) into animations (doodles).

P. Harless (2011) notes that scribing is an innovative technology that helps to focus listeners' attention on the key elements of the report and to reveals the connections between them. V.A. Pashkova and Yu.F. Katkhanova (2019), who examined the peculiarities of mastering the scribing technique, note in their research that the main advantages of scribing are universality of visualization, minimal costs, the connections between audio and visual information, and universality of the usage.

According to some researchers, scribing exists both in online and offline versions (Petrovskii et al., 2016). The difference between these versions is that offline scribing combines structural and logical diagrams and comics, which are performed by the teacher in the process of the explanation of the new material. As for online scribing, it is a video (or diagram-drawing) created by the teacher or by the combined efforts of students with the help of special computer programs. Thus, both versions of scribing can be used by the teacher in the classroom.

Today, two types of scribing exist: scribe presentation and video scribing.

Scribe presentation is the most widespread and well-known technique, it complements the speaker's speech with various schemes, pictures, and graphs, and reflects the key concepts of the story and the connections between them. In our opinion, it is important not only to demonstrate a ready-made scribe presentation, which is an expression of the teacher's creativity but also to involve students in the process of its creation during the lesson. An effective educational process can only be created by expanding the cooperation between students interested in gaining in-depth knowledge as the basis for their professional development, and the teacher who seeks to create interesting educational content to enhance the cognitive interest. 
Video scribing (doodling) is a method of transferring graphic information using a "drawing hand". This type of scribing is very popular, it evokes positive emotions, arouses interest because, in the process of perception, both the visual and auditory components of the narration are included, which increases the effectiveness.

Scribing is a multifunctional tool, thus, new opportunities appear for modernization of distance learning methods, for example, during English lexicology class. According to one of the interviewed experts, during the lesson devoted to the word and its meaning, diagrams, presented with the help of scribing, can accompany the oral presentation of the material, which makes it possible to present more clearly the information about the meaning of English words (Figure 1) and the structure of their lexical meaning (Figure 2).

Figure 1. The meaning of English words.

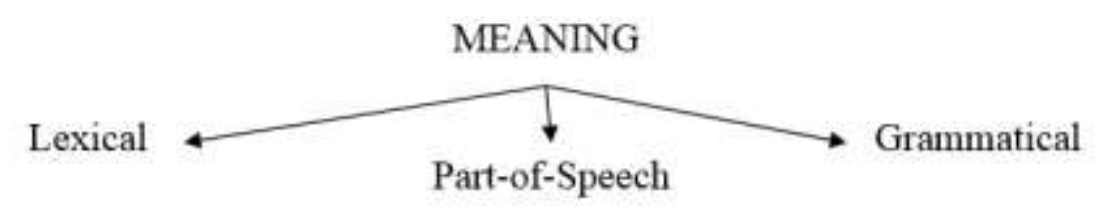

Figure 2. The structure of the lexical meaning of English words.

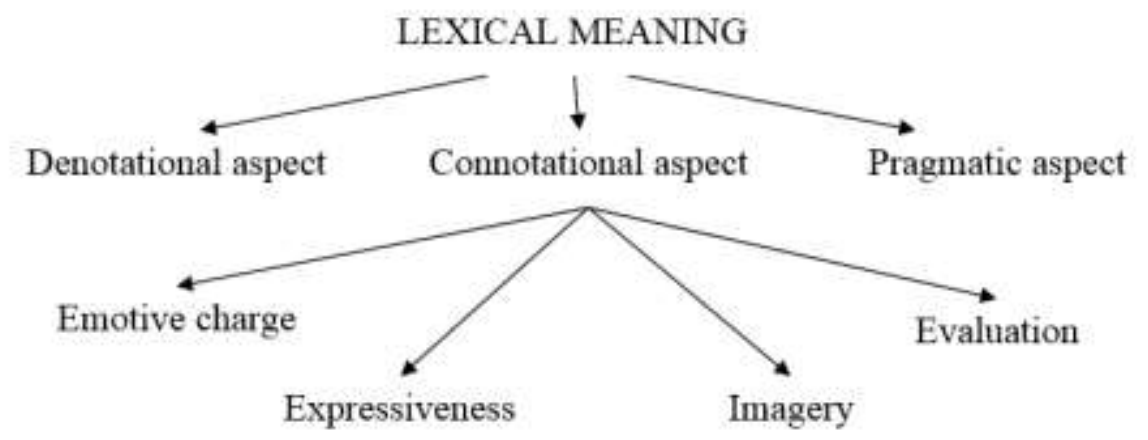

Video scribing helps to describe the realities of the English-speaking countries during the acquaintance with a foreign-language culture. The following scheme is used during the "Regional variants and dialects" course and shows the difference between British English and American English (Figure 3).

Figure 3. Characteristics of the university teaching staff.

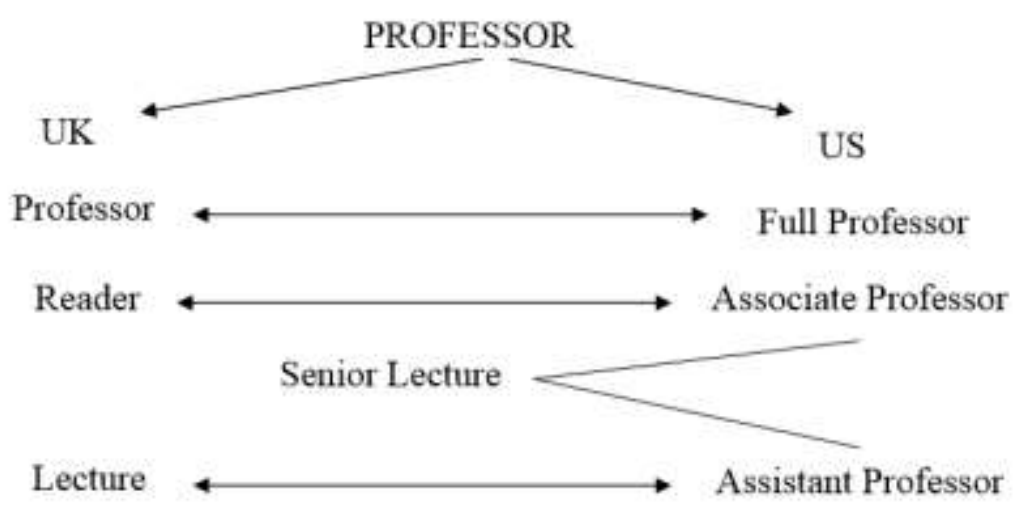




\section{CONCLUSION}

The use of visualization technology aimed at the repetition, generalization, and systematization of the listeners' knowledge helps not only to create a specific, visual-figurative representation of an examined object, phenomenon, or event but also to add new data or connections. The distance learning model with a complex visual impact became possible with the introduction of the latest ICT into the educational process: multimedia, interactive whiteboards, computer software for studying educational material, learning technologies via the Internet, etc. This is a new model of the system of transferring and gaining knowledge, which is based, in comparison with the traditional systems, on completely different psychological and pedagogical aspects. Considering all the above mentioned, it should be noted that the didactic significance of visualization in the educational process is manifested, first of all, in the implementation of the principle of visibility at a qualitatively new level. This allows creating a more progressive environment for the reflection of educational content, its visual interactive modeling, and research, which provides a student-centered developmental learning process.

The use of visualization technology in distance English language learning is aimed at focusing students' attention on key elements in the process of presenting educational material. The neat form of the presentation of the material, combined with expressive and authentic images that students can memorize easily, will help to create an optimal professional development path for future specialists.

The role of foreign language teachers is to consider all new trends in teaching, integrate students' computer perception of information into distance learning technology, and use visualization to enhance the learning process.

The role of visualization in distance foreign language learning is also worth emphasizing. Modern technologies offer a wide range of opportunities to increase the effectiveness of foreign language learning. Numerous teaching software allows organizing students' cognitive activity optimally; Internet sources offer the most modern authentic materials on any issue, which will undoubtedly contribute to the effective preparation of a future specialist for foreign language professional communication at different levels.

One of the important tasks of the teacher in the educational process is to help students develop the skills of processing visualized information in various graphic forms. This task is even more difficult in teaching a foreign language. Processing of integrated materials, preparation, and selection of suitable (ideally authentic) foreign language materials, logical integration of visualized data, increasing students' motivation to analyze information will not be successful if the teacher does not provide proper linguistic preparation of the group.

Thus, the results of the study confirmed the hypothesis that the use of visualization tools for distance English language learning involves a gradual implementation of the visualization of educational information using special visualization technologies.

Further research of methods of teaching foreign language communication can focus on the formation of the student's ability to independently produce an analytical text (orally or in writing) according to their speech intention based on visualized data both in the professional and academic spheres. The recommendations for writing a text part for the visualized content in a foreign language can also be included.

Authors' Contributions: Tatyana Ilinichna Golubeva: designed the study, prepared the plan, wrote the first draft of the manuscript and edited the final version. Elena Vladimirovna Skudnyakova: designed the study, prepared the plan, wrote the first draft of the manuscript and edited the final version. Natalia Nikolaevna Kasatkina: designed the study, prepared the plan, wrote the first draft of the manuscript and edited the final version. Svetlana Vladimirovna Dandanova: designed the study, prepared the plan, wrote the first draft of the manuscript and edited the final version. Oxana Innokentyevna Dagbaeva: designed the study, prepared the plan, wrote the first draft of the manuscipt and edited the final version. All authors have read and approved the final version of the manuscript. 
Ethics Approval: Not applicable.

Acknowledgments: Not applicable.

\section{REFERENCES}

Ahn, J. - W., \& Brusilovsky, P. (2009). Adaptive visualization of search results: Bringing user models to visual analytics. Information Visualization, 8(3), 167-179. http://dx.doi.org/10.1057/ivs.2009.12

Averbukh, V. L. (2013). Semiotika i osnovaniya teorii kompyuternoi vizualizatsii [Semiotics and foundations of the computer visualization]. Filosofskie problemy informatsionnykh tekhnologii i kiberprostranstva [Philosophical problems of IT and Cyberspace], 1(5), 26-41.

Azimov, E. G., \& Shchukin, A. N. (2009). Novyi slovar metodicheskikh terminov i ponyatii (teoriya i praktika obucheniya yazykam) [New dictionary of methodological terms and concepts (Theory and practice of language teaching)]. Moscow: Publishing House "IKAR", 448 p.

Bukhteeva, E. E., Zimovina, O. A., Shishov, S. E., Rabadanova, R. S., \& Polozhentseva, I. V. (2019). Practical and theoretical grounds of a student's autonomous learning activities in professional education. Amazonia Investiga, $8(20)$, 575-581.

Card, S. K., Mackinlay, J. D., \& Shneiderman, B. (1999). Readings in Information Visualization: Using vision to think. San Francisco: Morgan Kaufmann Publishers Inc., pp. 579-581.

Carr, C. S. (2003). Using computer supported argument visualization to teach legal argumentation. In: Kirschner, P. A., Buckingham-Shum, S. J., Carr, Ch. S. (Eds.). Visualizing argumentation: software tools for collaborative and educational sense-making. London: Springer-Verlag, pp. 75-96.

Dudin, M. N., Pogrebinskaya, E. A., Sidorenko, V. N., Sukhova, E. I., Zubenko, N. Yu., \& Shishalova, Ju. S. (2019). Crosscultural management in the system of harmonization of interests in the multi-confessional educational environment. European Journal of Science and Theology, 15(3), 191-199. https://doi.org/10.33051/1841-0464-2019-15-3-191-199

El Habbal Jadayel, R., \& Medlej, K. (2018). The pitching concept in contemporary education. International Journal of Arts \& Sciences, 11(01), 1-10.

Gilbert, J. (2005). Visualisation: a metacognitive skill in science and science education. In: Gilbert, J. K. (Ed.). Visualization in Science Education. Models and Modeling in Science Education, vol. 1. Dordrecht: Springer, pp. 9-27. https://doi.org/10.1007/1-4020-3613-2_2

Grebenyukov, V. I., Ed. (2014). Aktivnye i interaktivnye metody obucheniya [Active and interactive teaching methods]. Nizhnevartovsk: Publishing House of Nizhnevartovsk State University, 155 p.

Hall, K. W., \& Obregon, R. (2002). Applications and tools for design and visualization. The Technology Teacher, 61(7), 711.

Harless, P. (2011). Scribing: a technology-based instructional strategy. The Mathematics Teacher, 104(6), 420-425.

Izotova, N. V., \& Buglaeva, E. Yu. (2015). Sistema sredstv vizualizatsii v obuchenii inostrannomu yazyku [Visualization system in teaching a foreign language]. Vestnik Bryanskogo gosudarstvennogo universiteta [The Bryansk State University Herald], 2, 70-73.

Kiuru, K. V., \& Popova, E. E. (2018). Ispolzovanie tsifrovogo kontenta v obrazovatelnom protsesse VUZa kak otvet na vyzovy vizualnogo povorota [The use of digital content in the educational process of the university as a response to the challenges of the visual turn]. I. Yakovlev Chuvash State Pedagogical University Bulletin, 2, 91-102.

https://doi.org/10.25588/CSPU.2018.02.09

Klement, M. (2017). Models of integration of virtualization in education: Virtualization technology and possibilities of its use in education. Computers and Education, 105, 31-43. https://doi.org/10.1016/j.compedu.2016.11.006

Kodzova, Z. N. (2017). Vizualizatsiya kak printsip yazykovoi podgotovki [Visualization as one of the language learning principles]. Filologicheskie nauki. Voprosy teorii i praktiki [Philology. Theory \& Practice], 12-2(78), $209-211$.

Lavrentev, G. V., Lavrenteva, N. B., \& Neudakhina, N. A. (2012). Innovatsionnye obuchayushchie tekhnologii v professionalnoi podgotovke spetsialistov [Innovative teaching technologies higher education]. Barnaul: Publishing House of Altai State University, 231 p. 
Lengler, R., \& Eppler, M. J. (2007). Towards a periodic table of visualization methods for management. In: Proceedings of the IASTED International Conference on Graphics and Visualization in Engineering, Clearwater, Florida, USA, pp. 8388.

Lunsford, D. L. (2009). Virtualization technologies in information systems education. Journal of Information Systems Education, 20(3), 339-348.

Malkina, A. P. (2008). Vizualizatsiya kak sposob ponimaniya inoyazychnogo teksta po spetsialnosti $v$ obuchenii inostrannomu yazyku (neyazykovyi vuz) [Visualization as one of the ways of understanding a foreign language text in the field of study (in a non-linguistic university)]. Vestnik Tambovskogo universiteta. Seriya "Gumanitarnye nauki" [Journal "Tambov University Review. Series: Humanities"], 2(58), 239-245.

Paepcke-Hjeltness, V., Mina, M., \& Cyamani, A. (2017). Sketchnoting: A new approach to developing visual communication ability, improving critical thinking and creative confidence for engineering and design students. In: 2017 IEEE Frontiers in Education Conference (FIE), Indianapolis, IN, USA, pp. 1-5. https://doi.org/10.1109/FIE.2017.8190659

Pashkova, V. A., \& Katkhanova, Yu. F. (2019). Skraibing kak sredstvo vizualizatsii uchebnoi informatsii [Scribing as a means of visualizing educational information]. In: Murzina, Zh. V., Nikolaeva, G. V., Tolstov, N. S. (Eds.). Sovremennye tendentsii razvitiya sistemy obrazovaniya [Modern trends in the development of the education system]. Collection of articles, Issue 2. Cheboksary: Publishing House "Sreda", pp. 53-56.

Petrovskii, P., Lyubetskii, N., \& Kutuzova, M. (2016). Skraibing. Oyasnit prosto [Scribing. Simple to explain]. Moscow: Publishing House “Eksmo", 150 p.

Presnukhina, I. A., Sergeeva, M. G., Karavanova, L. Z., Belokon, O. V., \& Khvorikova, E. G. (2020). Development of research skills in the future foreign language teacher in the system of continuing education. Revista Tempos E Espaços Em Educação, 13(32), 1-24. https://doi.org/10.20952/revtee.v13i32.13370

Rabadanova, R. S., Bogatyreva, S. N., Artemieva, S. I., Aralova, E. V., Polozhentseva, I. V., \& Pisarevsky, K. L. (2020). Key features of human nutrition behavior. Revista Inclusiones, 7(S1-1), 170-181.

Reavey, P., Ed. (2010). Visual psychologies: using and interpreting images in qualitative research. London: Routledge, $416 \mathrm{p}$.

Rose, G. (2007). Visual Methodologies. An Introduction to Researching with Visual Materials. London: Sage, p. 240.

Sharonova, S., \& Avdeeva, E. (2020). Comparison of distance education and smart education. Revista Tempos $E$ Espaços Em Educação, 13(32), 1-15. https://doi.org/10.20952/revtee.v13i32.14689

Sidelnikova, T. T. (2016). Potentsial i ogranicheniya vizualizatsii kak metoda izucheniya sotsialno-gumanitarnykh distsiplin [Opportunities and limitations of visualization as a method of studying social science and humanities]. Integratsiya obrazovaniya [Integration of Education], 20(2), 281-292. https://doi.org/10.15507/19919468.083.020.201602.281-292

Stupina, S. B. (2009). Tekhnologii interaktivnogo obucheniya v vysshei shkole: uchebno-metodicheskoe posobie [Interactive learning technologies in higher education: a teaching guide]. Saratov: Publishing Center "Nauka", 52 p.

Syrina, T. A. (2016). Kognitivnaya vizualizatsiya: sushchnost ponyatiya i ego rol v obuchenii yazyku [Cognitive visualization: the concept and role in language teaching]. Vestnik TGPU [TSPU Bulletin], 7(172), 81-85.

Vinichenko, M. V., Chulanova, O. L., Oseev, A. A., Bogdan, E. S., Makushkin, S. A., \& Grishan, M. A. (2018). Interaction of the higher education and key employer for the formation of the actual profile of the competences of graduates of engineering directions. Modern Journal of Language Teaching Methods, 8(5), 393-403.

Volzhenina, N. V., \& Fomenko, N. I. (2013). Rol vizualizatsii uchebnoi informatsii v distantsionnom obuchenii [The role of the visualization of educational information in distance learning]. In: Instrumentalnaya didaktika i didakticheskii dizain: teoriya, tekhnologiya i praktika mnogofunktsionalnoi vizualizatsii znanii [Instrumental didactics and didactic design: theory, practice and techniques of multifunctional knowledge visualization]. Materials from the first AllRussian scientific and practical conference, Ufa, Russia, pp. 54-56.

Xu, W., Madison, K., Flinn, M., \& Kwok, W. (2014). Applying virtualization technology in security education. Procedia Social and Behavioral Sciences, 141, 10-14.

Zakharova, A. A., \& Shklyar, A. V. (2013). Metafory vizualizatsii [Visualization metaphors]. Nauchnaya vizualizatsiya [Scientific Visualization], 5(2), 16-24. 
Received: 11 June 2021 | Accepted: 10 July 2021 | Published: 26 July 2021

(c) (1)

This is an Open Access article distributed under the terms of the Creative Commons Attribution License, which permits unrestricted use, distribution, and reproduction in any medium, provided the original work is properly cited. 